Reviu Akuntansi dan Bisnis Indonesia, Vol. 2 No. 1, Hlm: 39-50, Juli 2018

Website: http://journal.umy.ac.id/index.php/rab

\title{
Pengaruh Corporate Social Responsibility, Kepemilikan Manajerial, Capital Intensity Dan Ukuran Perusahaan Terhadap Tax Aggressiveness : Studi Pada Perusahaan Jasa Sektor Property dan Real Estate yang Terdaftar di Bursa Efek Indonesia Tahun 2015-2017
}

\author{
Cahyaning Tiyas Utami; Afrizal Tahar \\ Program Studi Akuntansi Universitas Muhammadiyah Yogyakarta
}

IN F O A R T IKEL

\section{Kata Kunci:}

Corporate Social

Responsibility,

Kepemilikan Manajerial,

Capital Intensity, Ukuran

Perusahaan, Tax

Aggressiveness

Jenis Artikel:

Penelitian Empiris

Correspondence:

afrizal@umy.ac.id

\author{
A B S T R A K
}

Penelitian ini dilakukan untuk menguji pengaruh Corporate Social Responsibility, Kepemilikan Manajerial, Capital Intensity dan Ukuran Perusahaan terhadap Tax Aggressiveness. Populasi dalam penelitian ini adalah perusahaan jasa sektor property dan real estate yang terdaftar di Bursa Efek Indonesia (BEI) pada tahun 2015-2017.Dalam penelitian ini sampel dipilih menggunakan metode purposive samplingdan diperoleh 41 perusahaan yang menjadi sampel. Teknik pengumpulan data dalam penelitian ini dilakukan dengan teknik dokumentasi yaitu mengumpulkan sumber-sumber data dokumenter seperti laporan tahunan dan summary of financial statementperusahaan yang menjadi sampel penelitian atau diperoleh dari database Bursa Efek Indonesia (BEI) dan www.idx.co.id. Pengujian hipotesis menggunakan analisis regresi berganda.Pengolahan data dilakukan dengan menggunakan uji statistik regresi berganda dengan SPSS versi 15.0.Berdasarkan analisis yang telah dilakukan diperoleh hasil bahwa corporate social responsibilitytidak berpengaruh terhadap tax aggressiveness, kepemilikan manajerial tidak berpengaruh terhadap tax aggressiveness, capital intensity tidak berpengaruh terhadap tax aggressivenessdan ukuran perusahaan berpengaruh negatif terhadap tax aggressiveness.

(C) 2019 RAB. Published by Universitas Muhammadiyah Yogyakarta

\section{PENDAHULUAN}

Sumber penerimaan negara berasal dari berbagai sektor, yaitu dari sektor eksternal dan internal. Penerimaan negara dari sektor eksternal salah satunya berasal dari pinjaman luar negeri sedangkan yang berasal dari sektor internal adalah berasal dari pajak. Menurut Soemitro dalam Mardiasmo (2016) menyatakan bahwa pajak adalah iuran rakyat kepada kas negara yang diatur dalam undang-undang (yang dapat dipaksakan) dengan tidak adanya timbal balik secara langsung dapat ditunjukan dan digunakan untuk pengeluaran umum. Sesuai dengan Undang-undang Nomor 15 Tahun 2009 pasal 1 ayat 1, pajak merupakan kontribusi wajib dari Wajib Pajak orang pribadi atau badan kepada negara yang bersifat memaksa, digunakan untuk keperluan negara bagi kemajuan pembangunan dan kemakmuran rakyat serta diatur dalam undang-undang. Pajak merupakan sumber penerimaan negara yang sangat penting untuk keberlangsungan perekonomian 
negara Indonesia sekaligus menjadi penerimaan terbesar bagi Anggaran Pendapatan dan Belanja Negara (APBN). Hal tersebut menjadikan pajak sebagai tumpuan dalam kegiatan perekonomian Indonesia.

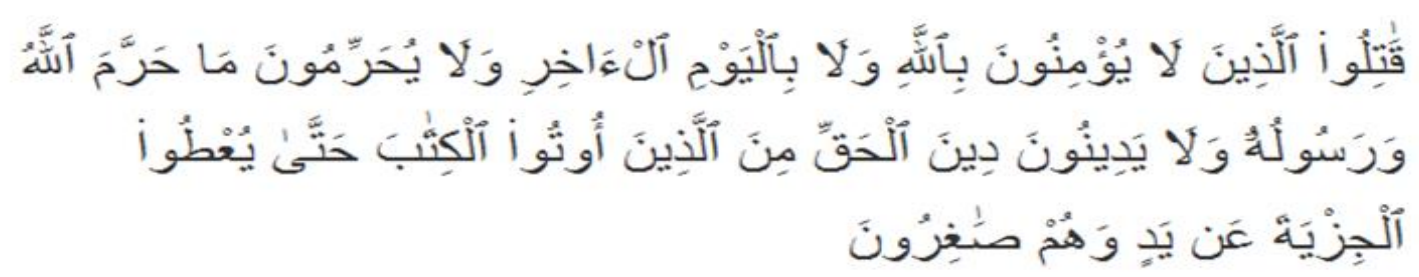

Artinya : Perangilah orang-orang yang tidak beriman kepada Allah dan tidak (pula) kepada hari kemudian dan mereka tidak mengharamkan apa yang telah diharamkan oleh Allah dan Rasul-Nya dan tidak beragama dengan agama yang benar (agama Allah), (yaitu orang-orang) yang diberikan alKitab kepada mereka, sampai mereka membayar jizyah dengan patuh sedang mereka dalam keadaan tunduk. (QS. 9:29)"

Dalam ayat diatas telah mengatakan, bahwa pajak dipungut sebagai wujud kewajiban yang harus dilaksanakan rakyat secara patuh untuk menghimpun dana bagi pemerintah. Pada masa kini, pemungutan pajak berlandaskan Undang - undang Dasar 1945 dan Pancasila. Pemungutan pajak dilakukan dari rakyat, oleh rakyat, dan untuk rakyat, yang menunjukan bahwa sistem dan mekanismenya menjadi ciri tersendiri dalam sistem perpajakan Indonesia. Allah SWT telah memerintahkan membayar pajak dan zakat dan menjadikan salah satu cara mendekatkan diri kepada-Nya. Ini merupakan suatu perintah yang harus dilaksanakan.

Namun, pajak atas penghasilan yang harus dibayar oleh Wajib Pajak merupakan beban bagi perusahaan sehingga pemilik perusahaan cenderung mengharapkan adanya pengurangan pajak yang akan dibayar dengan agresivitas pajak (Chen et al. 2008). Perusahaan yang merupakan entitas yang mempunyai kewajiban perpajakan menganggap bahwa pembayaran pajak merupakan biaya yang akan mengurangi laba bersih. Keadaan itulah yang membuat perusahaan mencari cara untuk mengurangi biaya pajak yang dibayar. Setiap perusahaan yang peduli akan melakukan perencanaan pajak membutuhkan keterbukaan transparansi terkait dengan situasi keuangan, kinerja dan tata kelola perusahaan, dengan tingkat transparansi tinggi yang memungkinkan pengurangan kerugian bagi pemegang saham (Kusumawati, 2016). Tax aggressiveness pada perusahaan merupakan tindakan merekayasa Pendapatan Kena Pajak (PKP), yang dapat dilakukan dengan perencanaan pajak (tax planning) baik menggunakan cara yang diizinkan (legah) maupun tidak (illegah). Untuk mehihat seberapa agresif perusahaan melakukan penghindaran pajak, dapat dilakukan dengan melihat dan menilai seberapa besar perusahaan melakukan kegiatan dalam rangka menghindari pembayaran pajak dengan memanfaatkan celah yang ada dalam peraturan perundang-undangan perpajakan. Semakin besar perusahaan mengambil langkah penghindaran pajakmaka dapat dikatakan bahwa perusahaan semakin agresif.

Faktor yang dapat mempengaruhi tax aggressiveness adalah Corporate Social Responsibility (CSR). CSR dapat diartikan "bagaimana perusahaan memperhitungkan dampak sosial dan lingkungan dalam cara perusahaan itu beroperasi, memaksimalkan manfaat dan meminimalkan kerugian” (PMKG dalam Yoehana, 2013). Kesadaran perusahaan dalam melaksanakan CSR ini akan berbeda satu sama lain. Menurut Yoehana (2013), perusahaan yang menyadari pentingnya tanggung jawab sosial maka perusahaan akan semakin memahami pentingnya kontribusi dalam melakukan pembayaran pajak. Kepemilikan manajerial juga merupakan salah satu faktor yang dapat mempengaruhi tax aggressiveness. Manajer perusahaan yang mempunyai wewenang dalam perusahaan dapat bertindak sesuai keinginannya guna meningkatkan kesejahterannya, walaupun menggunakan cara yang berpengaruh buruk terhadap kepentingan pemegang saham. Capital intensity atau rasio intensitas modal juga dimungkinkan merupakan faktor yang mempengaruhi perusahaan melakukan tindakan pajak agresif. Jumlah kepemilikan saham oleh manajemen juga dapat mempengaruhi jumlah dana yang dikeluarkan untuk aktivitas operasi guna memperoleh 
keuntungan perusahaan. Perhitungan pajak dilakukan dengan mengurangkan penghasilan dengan biaya depresiasi yang mengakibatkan jumlah penghasilan kena pajak berkurang. Perusahaan yang besar tentunya akan menjadi perhatian masyarakat khususnya pemerintah karena dianggap mempunyai laba yang besar maka akan dikenakan pajak atas labanya yang sepadan pula. Ukuran perusahaan yang besar maka aktivitas perusahaan untuk melakukan penghindaran pajak akan semakin besar pula (Ardyansyah dan Zulaikha, 2014). Faktor yang diperkirakan dapat mempengaruhi Wajib Pajak melakukan tindakan tax aggressiveness seperti Corporate Social Responsibility, Kepemilikan Manajerial, Capital Intensity dan Ukuran Perusahaan.

\section{TINJAUAN LITERATUR DAN PERUMUSAN HIPOTESIS}

\section{Teori Agensi (Agency Theory)}

Jensen dan Meckling (1976), teori agensi menjelaskan mengenai hubungan dan kontrak dimana salah satu pihak berperan sebagai pemberi wewenang (principa) dan pihak lainnya sebagai pihak yang diberi wewenang (agent). Dalam pemberian wewenang, terdapat kesepakatan antara pemilik perusahaan dengan pihak manajemen untuk mengelola perusahaan dengan tujuan utama yaitu memaksimalkan laba.

\section{Teori Legitimasi (Legitimacy Theory)}

Dowling dan Preffer (1975) dalam Muzakki dan Darsono (2015) menjelaskan bahwa dalam teori legitimasi perusahaan sebagai organisasi akan berusaha menciptakan keselarasan antara kegiatan yang dilakukan perusahaan dengan nilai-nilai atau norma yang berlaku pada lingkungan sosial dimana organisasi tersebut merupakan bagian dari lingkungan sosial. Dasar teori legitimasi adalah adanya kontrak sosial antara organisasi dengan masyarakat dimana organisasi itu berada.

\section{Teori Stakeholder (Stakeholder Theory)}

Donaldson dan Preston (1995) menjelaskan bahwa kinerja sebuah organisasi dipengaruhi oleh semua stakeholder dalam organisasi, maka dari itu pihak manajemen berkewajiban untuk memberikan keuntungan kepada seluruh stakeholder yang ada dalam organisasi. Teori stakeholder menjelaskan bahwa operasi perusahaan bukan hanya ditujukan untuk kepentingan pemilik saham, melainkan kepada seluruh pemangku kepentingan lain seperti kreditor, konsumen, supplier, pemerintah dan masyarakat (Ghozali dan Chariri dalam Nugraha, 2015).

\section{Corporate Social Responsibility}

CSR merupakan sebuah komitmen perusahaan untuk berkontribusi dalam melaksanakan pembangunan perekonomian yang berkelanjutan secara etis. Perusahaan dapat melakukan berbagai kegiatan untuk mewujudkan CSR, diantaranya adalah melakukan penanaman pohon sebagai bentuk dukungan go green, pembangunan sarana sosial, pemberiaan tunjangan kepada karyawan, memberikan lapangan pekerjaan bagi masyarakat sekitar untuk bekerja di perusahaan dan membuka kesempatan magang bagi siswa SMA/SMK serta mahasiswa dan berbagai hal lainnya (Yunistiyani dan Tahar, 2017). Perusahaan dituntut untuk menyeimbangkan pencapaiannya dalam bidang-bidang perekonomian (profit), kinerja sosial (people) dan kinerja lingkungan (planet) yang saat ini dikenal dengan istilah triple bottom line.

\section{Kepemilikan Manajerial}

Kepemilikan manajerial merupakan bagian kepemilikan saham biasa perusahaan olehpihak manajemen (Besley dan Brigham dalam Atari, 2016). Penerapan kepemilikan manajerial sesuai 
dengan teori agensi (agency theory) yang menyatakan bahwa terdapat konflik di dalam perusahaan antara pemegang saham dengan manajer. Peningkatan kepemilikan manajerial ditujukan sebagai cara untuk mengurangi konflik perusahaan (Jensen et al. dalam Hartadinata dan Tjaraka, 2013). Konflik tersebut muncul sebagai akibat dari perbedaan kepentingan antara pemegang saham dengan manajer. Kepemilikan manajerial merupakan kondisi dimana manajer memiliki saham perusahan atau dapat dikatakan bahwa manajer perusahaan bertindak sekaligus sebagai pemegang saham (Tjileni, 2013).

\section{Capital Intensity}

Capital intensity merupakan aktivitas investasi perusahaan yang dikaitkan dengan investasi aset tetap dan persediaan. Capital intensity atau rasio intensitas modal juga dapat diartikan dengan bagaimana perusahaan berkorban mengeluarkan modal atau dana untuk aktivitas perusahaan guna memperoleh keuntungan perusahaan. Capital intensity dapat menunjukan seberapa efisien perusahaan dalam menggunakan asetnya guna menghasilkan penjualan (Yoehana, 2013). Dengan kata lain, capital intensity merupakan bagaimana perusahaan mengeluarkan pendanaan dalam aktivitas perusahaan dengan mendapatkan keuntungan sebagai tujuannya.

\section{Ukuran Perusahaan}

Bujaki dan Richardson (1997) dalam Hartadinata dan Tjaraka (2013), ukuran perusahaan menggambarkan besar kecilnya suatu perusahaan yang dapat dinyatakan dengan total aset dan total penjualan bersih. Ukuran perusahaan merupakan suatu skala atau nilai yang dapat digunakan untuk mengklasifikasikan perusahaan ke dalam kategori besar atau kecil berdasarkan total hasil, log size dan lain-lain. Total aset yang besar mengindikasikan bahwa perusahaan memiliki ukuran yang besar. Semakin besar total aset perusahaan maka ukuran perusahaan akan semakin besar dan transaksi yang dilakukan akan semakin kompleks.

\section{Tax Aggressiveness}

Definisi tax aggressiveness yang digunakan oleh Frank et al. (2008) dalam Hartadinata dan Tjaraka (2013), dimana tindakan tersebut bertujuan untuk mengurangi PKP melalui perencanaan pajak (tax planning) baik secara legal (tax avoidance) maupun illegal (tax evasion). Kegiatan agresivitas pajak yang paling ekstrim adalah tax avoidance (Ying, 2011). Walaupun tindakan perencanaan pajak tidak seluruhnya dikatakan melanggar hukum, namun apabila semakin banyak celah yang digunakan perusahaan maka perusahaan dianggap semakin agresif.

Agresivitas pajak hampir terjadi di seluruh perusahaan, baik perusahaan kecil maupun besar. Tindakan agresivitas pajak ini bertujuan untuk meminimalkan biaya pajak dari biaya pajak yang telah diperkirakan. Manfaat agresivitas pajak adalah penghematan pengeluaran atas pajak sehingga keuntungan yang diperoleh dapat digunakan untuk investasi perusahaan sehingga dapat memberikan keuntungan untuk perusahaan di masa yang akan datang (Suyanto dan Supramono, 2012). Namun, tindakan agresivitas pajak yang dilakukan perusahaan dapat mengurangi penerimaan pajak kepada negara.

\section{Penurunan Hipotesis}

\section{Corporate Social Responsibility dan Tax Aggressiveness}

Sesuai dengan teori legitimasi, perusahaan sebaiknya melakukan berbagai cara untuk meyakinkan masyarakat bahwa segala bentuk kegiatan operasi perusahaan sesuai dengan norma dan nilai yang ada dalam masyarakat, sehingga kegiatan yang dilakukan dapat diterima dengan baik oleh masyarakat (Yoehana, 2013). Salah satunya dengan membayar pajak tanpa melakukan agresivitas pajak. Pajak perusahaan hanya dapat dikaitkan dengan CSR jika pembayaran pajak yang 
dilakukan perusahaan memang memiliki implikasi untuk masyarakat luas (Avi-Yonah dalam Richardson dan Lanis, 2012). Semakin tinggi tingkat pengungkapan CSR yang dilakukan oleh perusahaan maka perusahaan tersebut semakin tidak agresif terhadap pajak. penelitian Yoehana (2013) menyatakan bahwa CSR berpengaruh positif terhadap tax aggressiveness. Maka dirumuskan hipotesis sebagai berikut:

\section{$H_{t} \quad$ : Corporate Social Responsibility berpengaruh positif terhadap Tax Aggressiveness.}

\section{Kepemilikan Manajerial dan Tax Aggressiveness}

Struktur kepemilikan yang ada di perusahaan salah satunya adalah kepemilikan manajerial. Berdasarkan teori agensi, hubungan antara pemilik perusahaan atau pemegang saham dengan manajer rawan terjadi masalah keagenan. Permasalahan keagenan tidak sepenuhnya dapat diatasi melalui kebijakan insentif tetapi diperlukan juga kebijakan baru melalui peningkatan kepemilikan manajerial. Hal-hal yang dilakukan untuk mengurangi masalah keagenan adalah dengan adanya kepemilikan manajerial dan kebijakan hutang (Iqbal dalam Praditia, 2010). Perusahaan meningkatkan kepemilikan manajerial untuk mensejajarkan kedudukan manajer dengan pemegang saham sehingga bertindak sesuai keinginan dan kebaikan pemegang saham yang tidak lain termasuk manajer. Penelitian yang dilakukan oleh Ying (2011) menyatakan bahwa kepemilikan manajerial berpengaruh positif terhadap tax aggressiveness. Maka dirumuskan hipotesis sebagai berikut:

\section{$H_{2} \quad$ : Kepemilikan Manajerial berpengaruh positif terhadap Tax Aggressiveness.}

\section{Capital Intensity dan Tax Aggressiveness}

Capital intensity seringkali dikaitkan dengan seberapa besar aset tetap dan persediaan yang diinvestasikan oleh perusahaan. Adanya depresiasi aset tetapdapat menyebabkan berkurangnya beban pajak yang harus dibayarkan (Nugraha dan Meiranto, 2015). Sesuai dengan agency theory, setiap individu akan bertindak sesuai keinginan mereka sendiri khususnya perbedaan kepentingan antara pemegang saham (principa) dan manajemen (agent). Kepentingan manajemen adalah untuk mendapatkan kompensasi dengan meningkatkan kinerja perusahaan. Dalam hal ini manajemen dapat memanfaatkan penyusutan aset tetap untuk menekan beban pajak penghasilan. Manajer akan menggunakan dana yang menganggur untuk diinvestasikan pada aset tetap, sehingga penyusutan akan menjadi lebih besar dan besar beban pajak penghasilan yang harus dibayarkan akan menurun. Sehingga kinerja perusahaan akan meningkat seiiring penurunan beban pajak (Muzakki dan Darsono, 2015). Penelitian yang dilakukan oleh Hanum dan Zulaikha (2013) menyatakan bahwa capital intensity mempunyai pengaruh positif terhadap tax aggressiveness. Maka dirumuskan hipotesis sebagai berikut:

\section{$\boldsymbol{H}_{3} \quad$ : Capital Intensity berpengaruh positif terhadap Tax Aggressiveness.}

\section{Ukuran Perusahaan dan Tax Aggressiveness}

Sesuai dengan teori stakeholder, Segala tindakan yang ada dalam kegiatan perusahaan harus memberikan manfaat bagi seluruh pemangku kepentingan. Semakin besar aset yang dimiliki perusahaan diharapkan dapat menambah produktivitas perusahaan yang akan meningkatkan laba yang dapat dihasilkan. Laba yang didapatkan perusahaan itu tentunya akan memengaruhi besarnya pajak yang harus dibayar perusahaan. Berdasarkan uraian tersebut, besar kecilnya aset yang dimiliki perusahaan berhubungan dengan ukuran perusahaan. Semakin besar aset yang dimiliki maka semakin besar pula perusahaan tersebut. Namun, aset yang dimiliki perusahaan akan mengalami 
penyusutan setiap tahunnya, sehingga besar pajak yang harus dibayarkan akan menurun seiring dengan penyusutan tersebut. Penelitian yang dilakukan oleh Nugraha dan Meiranto (2015) juga menyatakan bahwa ukuran perusahaan berpengaruh negatif terhadap tax aggressiveness. Maka dirumuskan hipotesis sebagai berikut:

$\boldsymbol{H}_{4} \quad$ : Ukuran perusahaan berpengaruh negatif terhadap Tax Aggressiveness.

\section{METODE PENELITIAN}

Subjek atau objek penelitianini adalah perusahaan jasa sektor property dan real estate yang terdaftar di Bursa Efek Indonesia tahun 2015-2017. Sampel yang digunakan dalam penelitian ini ditentukan dengan purposive sampling, dengan kriteria:

1. Perusahaan jasa sektor property dan real estate yang terdaftar di Bursa Efek Indonesia untuk periode tahun 2015-2017

2. Perusahaan jasa sektor property dan real estate yang tidak mengalami kerugian untuk tahun 2015-2017

3. Perusahaan yang menyajikan laporan keuangan untuk tahun 2015-2017 dalam satuan mata uang rupiah (IDR)

4. Perusahaan yang mengungkapkan CSR dalam laporan tahunan untuk tahun 2015-2017

5. Perusahaan yang memiliki kepemilikan saham manajerial untuk tahun 2015-2017

Pengumpulan data dalam penelitian ini dilakukan dengan metode dokumentasi.

\section{Definisi Operasional Variabel}

\section{Variabel Independen}

Variabel independen adalah variabel yang mempengaruhi variabel dependen. Variabel independen pada penelitian ini ada empat, yaitu Corporate Social Responsibility, Kepemilikan Manajerial, Capital Intensity dan Ukuran Perusahaan. CSR diproksikan ke dalam pengungkapan CSR yang diukur menggunakan check list yang mengacu pada indikator pengungkapan yang digunakan secara umum di dunia yaitu Global Reporting Initiative G.4 (GRI G.4) menggunakan rumus:

$$
\mathrm{CSR}=\frac{\text { Item CSR Perusahaan }}{\text { Total Item Indikator GRI G.4 }}
$$

Menurut Besley dan Brigham dalam Hartadinata dan Tjaraka (2013), kepemilikan saham oleh pihak manajerial adalah bagian kepemilikan saham biasa perusahaan oleh pihak insider (pihak manajemen). Pada penelitian ini, kepemilikan manajerial diukur dengan rumus:

$$
\text { KepemilikanManajeial }=\frac{\text { Total Saham Manajer }}{\text { Total Saham Beredar }}
$$

Capital intensity dalam peneitian ini diproksikan menggunakan raiso intensitas aset tetap yang merupakan perbandingan aset tetap dengan total aset sebuah perusahaan. Berdasarkan penelitian Rodriguez dan Arias (2007) dalam Nugraha dan Meiranto (2015), capital intensity dapat dirumuskan sebagai berikut:

$$
\mathrm{CAPIN}=\frac{\text { Total Aset } \text { Tetap }}{\text { Total Aset }}
$$


Ukuran perusahaan merupakan total aset perusahaan yang digunakan sebagai skala pengklasifikasian perusahaan (Kuriah dan Arsyik dalam Renta, 2018). Ukuran perusahaan dapat diukur menggunakan natural logaritma total aset dengan rumus:

$$
\text { Size }=\operatorname{Ln}(\text { total aset })
$$

\section{Variabel Dependen}

Variabel dependen adalah variabel yang dipengaruhi oleh variabel-variabel lain. Dalam penelitian ini yang merupakan variabel dependen adalah tax aggressiveness. Tax aggressiveness atau tindakan pajak agresif merupakan salah satu cara yang dapat dilakukan oleh perusahaan untuk meminimalkan beban pajak, baik menggunakan cara penghindaran pajak (tax avoidance) maupun penggelapan pajak (tax evasion).

Tax aggressiveness dalam penelitian ini diukur dengan menggunakan pengukuran tax avoidance yaitu Effective Tax Rates (ETR). Perusahaan akan semakin agresif apabila nilai ETR semakin rendah. Rumus untuk mengukur ETR adalah:

$$
E T R=\frac{\text { Beban Pajak Penghasilan }}{\text { Laba Sebelum Pajak }}
$$

\section{HASIL DAN PEMBAHASAN}

\section{Hasil Penelitian (Uji Hipotesis)}

Uji Koefisien Determinasi (R Square dan Adjusted R²)

Tabel 1 Hasil Uji Koefisien Determinasi R Square

\begin{tabular}{ccccc}
\hline Model & $\mathrm{R}$ & R Square & $\begin{array}{c}\text { Adjusted } \\
\text { R Square }\end{array}$ & $\begin{array}{c}\text { Std. Error of the } \\
\text { Estimate }\end{array}$ \\
\hline 1 &, $558(\mathrm{a})$ &, 331 &, 243 &, 0339656 \\
\hline
\end{tabular}

Sumber: Output SPSS 2018

Tabel 1 menunjukan bahwa nilai Adjusted $\boldsymbol{R}$ Square sebesar 0,243 atau 24,3\% maka dapat dikatakan bahwa variabel CSR, kepemilikan manajerial, capital intensity, dan ukuran perusahaan sebesar $24,3 \%$ dan sisanya $(100 \%-24,3 \%=75,7 \%)$ dijelaskan oleh variabel independen lain yang tidak termasuk dalam penelitian ini.

\section{Analisis Regresi Linier Berganda}

\begin{tabular}{|c|c|c|c|}
\hline Model & $\begin{array}{c}\text { Standardized } \\
\text { Coefficients } \\
\text { Beta }\end{array}$ & $\begin{array}{c}\text { Sig } \\
\text { Std.Error }\end{array}$ & Kesimpulan \\
\hline${ }^{1}$ (Constant) & & ,000 & \\
\hline CSR &,- 064 & 667 & Ditolak \\
\hline Kepemilikan Manajerial & ,097 & ,498 & Ditolak \\
\hline Capital Intensity & ,035 & 807 & Ditolak \\
\hline Ukuran Perusahaan &,- 538 & 001 & DIterima \\
\hline
\end{tabular}

Tabel 2 Hasil Uji Analisis Regresi Linier Berganda

Sumber: Output SPSS 2018 


\section{Uji Parsial (Uji t)}

\section{Pengaruh CSR terhadap Tax Aggressiveness}

Berdasarkan Tabel 2 dapat dilihat bahwa variabel CSR memiliki nilai signifikansi sebesar 0,667 > 0,05 dengan nilai koefisien beta sebesar -0,043. Berdasarkan hasil diatas dapat disimpulkan bahwa CSR tidak berpengaruh terhadap tax aggressiveness. Maka hipoteis pertama $\left(\mathrm{H}_{\mathrm{H}}\right)$ ditolak.

\section{Pengaruh Kepemilikan Manajerial terhadap Tax Aggressiveness}

Berdasarkan Tabel 2 menunjukan bahwa variabel kepemilikan manajerial memiliki nilai signifikansi sebesar 0,498 > 0,05 dengan nilai koefisien beta sebesar 0,004. Berdasarkan hasil diatas dapat disimpulkan bahwa kepemilikan manajerial tidak berpengaruh terhadap tax aggressiveness. Maka hipotesis kedua $\left(\mathrm{H}_{2}\right)$ ditolak.

\section{Pengaruh Capital Intensity terhadap Tax Aggressiveness}

Berdasarkan Tabel 2 menunjukan bahwa variabel capital intensity memiliki nilai signifikansi sebesar 0,807>0,05 dengan nilai koefisien beta sebesar 0,009. Berdasarkan hasil diatas dapat disimpulkan bahwa capital intensity tidak berpengaruh terhadap tax aggressiveness. Maka hipotesis ketiga $\left(\mathrm{H}_{3}\right)$ ditolak.

\section{Pengaruh Ukuran Perusahaan terhadap Tax Agressiveness}

Berdasarkan Tabel 2 menunjukan bahwa variabel ukuran perusahaan memiliki nilai signifikansi $0,001<0,05$ dengan nilai koefisien beta sebesar $-0,13$. Berdasarkan hasil diatas dapat disimpulkan bahwa ukuran perusahaan berpengaruh terhadap tax aggressiveness. Maka hipotesis keempat $\left(\mathrm{H}_{4}\right)$ diterima.

\section{Pembahasan}

\section{Corporate Social Responsibility terhadap Tax Aggressiveness}

Berdasarkan hasil uji hipotesis menunjukan CSR tidak berpengaruh terhadap tax aggressiveness. Hal tersebut dapat dilihat dari hasil nilai signifikansi 0,667 >0,05, sehingga hipotesis 1 tertolak. Jesica dan Toly (2014) menyatakan bahwa CSR tidak berpengaruh terhadap tax aggressiveness. Penelitian tersebut menyatakan bahwa semakin besar perusahaan mengungkapkan CSR belum tentu perusahaan melakukan penghindaran pajak yang besar pula.

Kegiatan CSR perusahaan tidak mempengaruhi perusahaan untuk membayarkan beban pajak perusahaan lebih kecil. Manfaat bagi pemerintah akan terus meningkat dan kegiatan CSR dapat mendukung perkembangan masyarakat, tenaga kerja serta lingkungan secara berkelanjutan agar menjadi lebih baik. Selain itu, hubungan CSR dengan tindakan mengindari pajak hanya tertuang dalam laporan tahunan saja tanpa tahu apakah kegiatan CSR yang ada dalam indikator penilaian memang dilakukan atau tidak. Lalu penilaian indikator-indikator merupakan subjektifitas peneliti, mungkin beda peneliti dapat menghasilkan penilaian yang berbeda.

\section{Kepemilikan Manajerial terhadap Tax Aggressiveness}

Berdasarkan hasil uji hipotesis menunjukan bahwa kepemilikan manajerial tidak berpengaruh terhadap tax aggressiveness. Hal tersebut dapat dilihat dari nilai signifikansi 0,498 > 0,05 sehingga hipotesis ke 2 ditolak. Isetyowati (2016), yang mengatakan bahwa beberapa peraturan perlu dibuat untuk menyeimbangkan kekuatan pemegang saham dalam perusahaan.

Pemegang saham terbesar dalam perusahaan sebagian besar adalah perusahaan dalam negeri 
lain, sehingga kepemilikan saham manajemen cenderung memiliki jumlah yang sedikit. Hal tersebut mengakibatkan perusahaan tidak mau mengambil suatu risiko yang dapat merusak reputasi perusahaannya termasuk dalam pembayaran pajak, artinya kepemilikan saham oleh manajemen belum tentu berpengaruh terhadap tindakan menghindari pajak. Penelitian ini juga sejalan dengan penelitian yang oleh Putri dan Lautania (2016). Penelitian tersebut menyatakan peran manajer tidak memperngaruhi jumlah pajak yang harus dibayarkan.

\section{Capital Intensity terhadap Tax Aggressiveness}

Berdasarkan hasil uji hipotesis menunjukan bahwa capital intensity tidak berpengaruh terhadap tax aggressiveness dengan nilai signifikansi 0,807 > 0,05 sehingga hipotesis ke 3 ditolak. Rahmawati (2017) menyatakan tidak ada pengaruh antara variabel capital intensity dengan tax aggressiveness. Artinya, besar kecilnya intensitas modal suatu perusahaan tidak akan mempengaruhi perusahaan tersebut dalam melakukan penghindaran atau perencanaan pajak. Intensitas modal dilihat dari aset tetap dan total aset perusahaan yang tiap tahunnya akan mengalami penyusutan dan mempengaruhi beban pajak yang harus dibayarkan. Dalam perusahaan mekanisme penyusutan aset sudah diatur dalam PSAK No. 17. Sehingga tindakan yang mungkin dilakukan untuk memanipulasi penyusutan akan sulit dilakukan. Dapat dikatakan bahwa perusahaan akan melakukan dan menghitung penyusutan aset tetap sesuai dengan peraturan. Oleh karena itu tingkat tax aggressiveness dalam perusahaan tidak dipengaruhi oleh capital intensity.

\section{Ukuran Perusahaan terhadap Tax Aggressiveness}

Berdasarkan hasil uji hipotesis menunjukan bahwa ukuran perusahaan berpengaruh negatif terhadap tax aggressiveness. Hal tersebut dapat dilihat dari nilai signifikansi $0,001<0,05$, sehingga hipotesis 4 diterima. Hartadinata dan Tjaraka (2013) yang menyatakan hubungan antara ukuran perusahaan dengan tax aggressiveness mempunyai pengaruh negatif.

Semakin besar ukuran perusahaan maka semakin besar pula ETR atau rasio tarif pajak efektifnya. ETR akan berbanding terbalik dengan tindakan penghindaran pajak. Hal ini berarti bahwa semakin besar ukuran perusahaan maka semakin tidak agresif dalam kegiatan perpajakannya. Hal tersebut dapat terjadi karena perusahaan yang besar cenderung mempunyai sumber daya yang terkelola dalam perencanaan pajak. Perusahaan besar tidak ingin direpotkan dengan risiko pemeriksaan pajak yang dapat mengganggu operasional perusahaan sehingga perusahaan sebisa mungkin meningkatkan rasio pajak efektifnya.

\section{KETERBATASAN PENELITIAN}

Beberapa keterbatasan dalam penelitian ini adalah penelitian ini hanya meneliti Corporate Social Responsibility, Kepemilikan Manajerial, Capital Intensity dan Ukuran Perusahaan terhadap Tax Aggressiveness. Jangka waktu penelitian hanya tiga tahun dari tahun 2015-2017 sehingga sampel yang digunakan terbatas. Data yang didapat didasarkan pada laporan keuangan, sehingga kurang menggambarkan keadaan yang sebenarnya. Sampel perusahaan terbatas pada perusahaan jasa sektor property dan real estate dan hanya 41 perusahaan yang dapat diolah karena data lainnya tidak memenuhi kriteria. Penelitian ini hanya menggunakan sampel perusahaan jasa sektor property dan real estate sehingga penelitian ini tidak digunakan untuk menggeneralisasi seluruh sektor industri karena setiap sektor industri memiliki karakter yang berbeda

\section{KESIMPULAN}

Berdasarkan hasil penelitian dan pembahasan dapat disimpulkan CSR tidak berpengaruh terhadap tax aggressiveness pada perusahaan jasa sektor property dan real estate yang terdaftar di 
BEI tahun 2015-2017. Kepemilikan manajerial tidak berpengaruh terhadap tax aggressiveness pada perusahaan jasa sektor property dan real estate yang terdaftar di BEI tahun 2015-2017. Capital intensity tidak berpengaruh terhadap tax aggressiveness pada perusahaan jasa sektor property dan real estate yang terdaftar di BEI tahun 2015-2017. Ukuran perusahaan berpengaruh negatif terhadap tax aggressiveness pada perusahaan jasa sektor property dan real estate yang terdaftar di BEI tahun 2015-2017.

Beberapa saran dari penelitian ini dapat dijadikan pertimbangan untuk penelitian selanjutnya adalah bagi peneliti selanjutnya, sebaiknya menggunakan periode jangka waktu yang lebih panjang dalam mengukur tax aggressiveness. Penelitian ini hanya dilakukan pada perusahaan jasa sektor property dan real estate saja. Diharapkan peneliti selanjutnya dapat melakukan penelitian pada perusahaan lain yang memiliki tax aggressiveness yang tinggi yang terdaftar di BEI. Peneliti selanjutnya diharapkan dapat menambah variabel yang belum terdapat dalam penelitian ini seperti profitabilitas, leverage, kepemilikan institusional, dll

\section{DAFTAR PUSTAKA}

Al Qur'an. Surat At-Taubah Ayat 29

Anonym. Pajak Coca - cola Masih Kurang $R$ 4 49,2 Miliar". http:/pajakonline.com/engine/artikel/art.php/art.php?artid=10141._Diaksestanggal 18 Mei $2018 \mathrm{pk} 18.25$ WIB.

Ardyansyah, D. \& Zulaikha. (2014). Pengaruh Size, Leverage, Profitability, Capital Intensity Ratio dan Komisaris Independen terhadap Effective Tax Rate (ETR). Semarang: Universitas Diponegoro.

Atari, J. (2016). Pengaruh Kepemilikan Manajerial, Kepemilikan Institusional, dan Kebijakan Hutang Terhadap Tax Aggressive (Studi Empiris Pada Perusahaan Transportasi yang terdaftar di Bursa Efek Indonesia Periode 2011-2013).JOM Fekon. 3(1), 1137-1149.

Avi-Yonah, \& Reuven S. (2014). Corporate Taxation and Corporatee Social Responsibility.Journal of Law and Business, 11(1), 1-14.

Chen, S., Chen, X., Cheng, Q., \& Shevlin, T. (2008). Are Family Firms more Tax Aggressive than Non-family Firms?. Journal of Financial Economics.Research Collection School of Accountancy. 9 (1), 41-46.

Donaldson, T., \& Preston, L. (1995). The Stakeholder Theory of The Corporation: Concepts, Evidence, and Implications. Academy of Management Review. 20(1), 65-91.

Fatharani, N. (2012). Pengaruh Karakteristik Kepemilikan, Reformasi Perpajakan dan Hubungan Politiik Terhadap Tindakan Pajak Agresif Pada Perusahaan yang Terdaftar di BEI PadaTahun 2007-2010. Jakarta: Universitas Indonesia

Ghozali , I. (2011). Aplikasi Analisis Multivariate Dengan Program SPSS. Semarang: BP Universitas Diponegoro

Ghozali, I. (2009). Aplikasi Analisis Multivaraite dengan Program SPSS. Semarang: Universitas Diponegoro

Global Reporting Initiative. (2011). www.globalreporting.org. Diakses pada tanggal 20 Oktober 2019

Hanum, H. R., \& Zulaikha. (2013). Pengaruh Karakteristik Corporate Governance Terhadap Effective Tax Rate. Diponegoro.Journal of Accounting. 2(2), 1-10

Harjito, S. \& Yulianto. (2017). Tax Aggressiveness Seen From Company Characteristics and Coorporate Social Responsibility. Journal of Auditing, Finance and Forensic Accounting. 5(2), 77-91.

Hartadinata, O. S. \& Tjaraka, H. (2013). Analisis Pengaruh Kepemilikan Manajerial, Kebijakan Hutang, dan Ukuran Perusahaan Terhadap Tax Aggressiveness.(Pada Perusahaan Manufaktur di Bursa Efek Indonesia Periode Tahun 2008-2010). Jurnal Ekonomi dan Bisnis. 48-59.

Ikatan Akuntan Indonesia. (2015). ED Amandemen PSAK 16. Jakarta: Grha Akuntan 
Ikatan Akuntan Indonesia. (2015). ED Amandemen PSAK 17. Jakarta: Grha Akuntan

Irianto, B. S. dkk. (2017). The Influence of Profitability, Leverage, Firm Size and Capital Intensity Towards Tax Avoidance. International Journal of Accounting and Taxation. 5(2), 33-41.

Isetyowati. (2016). Pengaruh Kompensasi Eksekutif, Kepemilikan Saham Eksekutif, Preferensi Risiko Eksekutif dan Karakteristik terhadap Penghindaran Pajak Perusahaan (Studi Empiris pada Perusahaan Property, Real Estate dan Building Construction yang Terdaftar di BEI periode 2011-2015). Yogyakarta: Universitas Muhammadiyah Yogyakarta

Jensen, M.C. \& Meckling, W.H. (1976). Theory of the Firm: Manajerial Behavior, Agency Cost and Ownership Structure. Journal of Financial Economics. 3(4), 305-360

Jesicca \& Toly, A.A. (2014). Pengaruh Pengungkapan Corporate Social Responsibility terhadap Agresivitas Pajak. Tax \& Accounting Review. 4(1)

Kusumawati, W. T. (2016). The Effect of Institutional Ownership and Corporate Social Responsibility to the Tax Aggressive. Proceeding-International Conference of Banking, Accounting, Management and Economics \& Call For Papers (ICOBAME). 83-90

Latifah, N. U. (2018). Pengaruh Corporate Governance, Capital Intensity dan Inventory Intensity Terhadap Agresivitas Pajak. IAIN. Surakarta

Mardiasmo. (2016). Perpajakan Edisi Baru. Yogyakarta: Andi Yogyakarta

Maretha, R. A. (2016). Pengaruh Ukuran Perusahaan dan Debt to Equity Ratio Terhadap Nilai Perusahaan (Studi Pada Perusahaan Manufaktur Sektor Industri Dasar dan Kimia yang Terdaftar di Bursa Efek Indonesia Tahun 2010-2014). Bandung: Universitas Pasundan

Mustami, A. A. Coca-Cola Diduga Akali Setoran Pajak. https://ekonomi.kompas.com/read/2014/06/13/1135319/CocaCola.Diduga.Akali.Setoran.P ajak. Diakses tanggal 18 Mei pukul 19.00 WIB

Mustika. (2017). Pengaruh Corporate Social Responsibility, Ukuran Perusahaan, Profitabilitas, Leverage, Capital Intensity dan Kepemilikan Keluarga terhadap Agresivitas Pajak (Studi Empiris Pada Perusahaan Pertambangan dan Pertanian yang terdaftar di Bursa Efek Indonesia Periode Tahun 2012-2014).JOM Fekon. 4,(1)

Muzakki, M. R., \& Darsono. (2015). Pengaruh Corporate Social Responsibility dan Capital Intensity Terhadap Penghindaran Pajak. Diponegoro Journal of Accounting. 4 (3). 1-8

Nazaruddin, I, \& Basuki, A. T. (2015). Analisis Statistik Dengan SPSS. Yogyakarta: Danisa Media

Nugraha, N. B., \& Meiranto, W. (2015). Pengaruh Corporate Social Responsibility, Ukuran Perusahaan, Profitabilitas, Leverage dan Capital Intensity terhadap Agresivitas Pajak (Studi Empiris Pada Perusahaan Non Keuangan yang Terdaftar di BEI Tahun 2012-2013). Diponegoro Journal of Accounting. 4 (4), 1-14

Praditia, O. R. (2010). Analisis Pengaruh Mekanisme Corporate Governance Terhadap Manajemen Laba dan Nilai Perusahaan Pada Perusahaan Manufaktur yang Terdaftar di Bursa Efek Indonesia (BEI) PadaTahun 2005-2008. Semarang: Universitas Diponegoro

Pradnyadari, I. D. A. I. (2015). Pengaruh Pengungkapan Corporate Social Responsibility Terhadap Agresivitas Pajak (Studi Empiris Pada Perusahaan Manufaktur Yang Terdaftar Di Bursa Efek Indonesia Tahun 2011-2013). Semarang: Universitas Diponegoro

Putri, C. L. \& Lautania, M. F. (2016). Pengaruh Capital Intensity Ratio, Inventory Intensity Ratio, Ownership Structure dan Profitability Terhadap Effective Tax Rate (ETR). Jurnal Ilmiah Mahasiswa Akuntansi. 1(1). 101-119

Rahmawati, L. (2017). Pengaruh Intensitas Modal, Sales Growth Dan Karakter Eksekutif Terhadap Tax Avoidance Dengan Leverage Sebagai Variabel Intervening (Studi Empiris Pada Perusahaan Manufaktur Yang Terdaftar Di BEI Periode 2014-2016)

Rahmiyati, A. N. A. (2017). Pengaruh Pengungkapan Corporate Social Responsibility dan Struktur Kepemilikan Terhadap Agresifitas Pajak Dengan Komisaris Independen Dan Komite Audit Sebagai Variabel Moderasi (Studi Empiris di Perusahaan Manufaktur yang Terdaftar di BEI Tahun 2010-2015). Yogyakarta: Universitas Muhammadiyah Yogyakarta

Ratmono, D., \& Sagala, W. M. (2015). Pengungkapan Corporate Social Responsibility (CSR) Sebagai Sarana Legitimasi: Dampaknya Terhadap Tingkat Agresivitas Pajak. Jurnal Nominal. 4(2). 165-329 
Renta, M. P. P. (2018). Pengaruh Pengungkapan Corporate Social Responsibility dan Mekanisme Corporate Governance Terhadap Agresivitas Pajak. (Studi Empiris pada Perusahaan Manufaktur yang Terdaftar di BEI Periode 2015-2016). Yogyakarta: Universitas Muhammadiyah Yogyakarta

Richardson, G., \& Lanis, R. (2012). Corporate Social Responsibility and Tax Aggressiveness : a Test of Legitimacy Theory. Accounting, Auditing \& Acountability Journal. 26(1), 75-100

Rusydi, M. K. (2013). Pengaruh Ukuran Perusahaan Terhadap Aggressive Tax Avoidance di Indonesia. Jurnal Akuntansi Multiparadigma. 4(2)

Sari, D. L. (2017). Pengaruh Corporate Social Responsibility, Kepemilikan Mayoritas dan Corporate Governance Terhadap Agresivitas Pajak (Studi pada Perusahaan Manufaktur yang Terdaftar di BEI Tahun 2011-2014). JOM Fekon. 4(1), 1813-1827

Seprini. (2016). Pengaruh Good Corporate Governance dan Corporate Social Responsibility Terhadap Tindakan Pajak Agresif. (Studi pada Perusahaan Pertambangan yang Terdaftar di BEI 2011-2013). JOM Fekon. 3 (1), 2238-3352

Setiawan, D. A. Kini giliran IKEA Terjerat Kasus Penghindaran Pajak”.http://news.ddtc.co.id/kinigiliran-ikea-terjerat-kasus-penghindaran-pajak-11556. Diakses tanggal 18 Mei pk. 19.15 WIB

Siregar, R., \& Widyawati, D. (2016). Pengaruh Karakteristik Perusahaan Terhadap Pengungkapan CSR. Jurnal IImu dan Riset Akuntansi. 5(1), 1-17

Sunaryo. (2016). Effect of Family Ownership Toward Tax Aggressiveness on Food and Beverages Industrial Company Listed in Indonesia Stock Exchange. Bina Nusantara Business Review. 7, (1), 53-57

Suyanto, K. D. \& Supramono. (2012). Likuiditas, Leverage, Komisaris Independen, dan Manajemen Laba Terhadap Agresivitas Pajak Perusahaan. Jurnal Keuangan dan Perbankan. 16(2), 167-177

Tjileni. (2013). Kepemilikan Manajerial Dan Institusional Pengaruhnya Terhadap Kebijakan Hutang Pada Perusahaan Manufaktur di Bursa Efek Indonesia. Jurnal EMBA, 1(2), 129-139

Undang-undang Pemerintah Republik Indonesia, Undang-undang No. 15 Tahun 2009 pasal 1 ayat 1 tentang Perpajakan

Undang-undang Pemerintah Republik Indonesia, Undang-undang No. 40 Tahun 2007 pasal 1 ayat 3 tentang Perseroan Terbatas

Utami, W. T., \& Setyawan, H. (2015). Pengaruh Kepemilikan Keluarga terhadap Tindakan Pajak Agresif dengan Corporate Governance sebagai Variabel Moderating. (Studi Empiris Pada Perusahaan Manufaktur yang Terdaftar di BEI Tahun 2010-2013). CBAM. 1(2), 413-421

World Business Council in Sustainable Development. Corporate Social Responsibility.https://www.wbcsd.org/work-program/business-role/previous-work/corporatesocial-responsibility.aspx. Diakses tanggal 5 November pk. 08.00 WIB

Ying, Z. (2011). Ownership Structure, Board Charactheristics and Tax Aggressive. Lingnan University

Yoehana, M. (2013). Analisis Pengaruh Corporate Social Responsibility terhadap Agresivitas Pajak (Studi Empiris Pada Perusahaan Manufaktur yang Terdaftar di BEI Tahun 2010-2011). Semarang: Fakultas Ekonomika dan Bisnis. Universitas Diponegoro

Yunistiyani, V., \& Tahar, A. (2017). Corporate Social Responsibility dan Agresivitas Pelaporan Keuangan Terhadap Agresivitas Pajak dengan Good Corporate Governance Sebagai Pemoderasi. (Studi pada Perusahaan Manufaktur di Bursa Efek Indonesia).Jurnal Akuntansi dan Investasi Universitas Muhammadiyah Yogyakarta, 2(1), 01-31 